Reprod. Nutr. Dévelop., 1983, 23 (2 B), 321-327.

\title{
Metabolism of glucose and mannose anomers in pancreatic islets
}

\author{
W. J. MALAISSE (1), Francine MALAISSE-LAGAE, A. SENER
}

Laboratory of experimental Medicine, Brussels University, Medical School, Brussels, Belgium.

Summary. The $\alpha$-anomers of D-glucose and D-mannose stimulate insulin release more efficiently than the corresponding $\beta$-anomers. This coincides with higher glycolytic and oxidative fluxes in pancreatic islets exposed to $\alpha$ - than to $\beta$-anomers. This situation may be attributable, in the case of $\alpha$-D-glucose, not solely to the $\alpha$-stereospecificity of phosphoglucose isomerase but also to that of phosphoglucomutase resulting in a higher islet content of glucose-1,6-bisphosphate, an activator of phosphofructokinase. Likewise, more aldohexose-bisphosphate accumulates in the islets exposed to $\alpha$-D-mannose than in those incubated with $\beta$-D-mannose. The anomeric specificity of hexose metabolism in pancreatic islets supports the fuel hypothesis for insulin release.

\section{Introduction.}

For more than a decade, we have defended the view that the process of nutrient-stimulated insulin release represents the outcome of a series of metabolic, ionic and motile events (Malaisse, 1972, 1973). Considerable progress has been made on this topic over the last 3 years since it was the object in 1979 of both a 3-day workshop (Malaisse and Täljedal, 1980) and a short symposium (Malaisse, 1980). As a matter of fact, the information gained recently on the regulation of islet metabolism, the coupling of metabolic and ionic events, the handling of ions by islet cells and the behaviour of insulin secretory granules prior to and at the time of exocytosis is so abundant (Malaisse, 1981) that it cannot be accommodated within the limits imposed to this contribution. Hence, this report is restricted to a reconsideration of the earliest step in the secretory sequence, namely that step which concerns the identification of nutrients as stimuli of insulin release.

The modality of nutrients identification by the pancreatic B-cell is the object of an apparently endless dispute between the supporters of the receptor hypothesis and those of the metabolic hypothesis, respectively. The receptor

(1) Mailing address: Dr. W. J. Malaisse, Laboratoire de Médecine Expérimentale, 115, boulevard de Waterloo, Bruxelles B-1000, Belgique. 
hypothesis postulates that nutrients initiate the secretory sequence by activating stereospecific membrane receptors. The metabolic theory, that we reformulated as a fuel hypothesis (Malaisse et al., 1979), postulates that the capacity of nutrients to stimulate insulin release depends on their capacity to augment catabolic fluxes in the islet cells. In a recent publication, we have indicated that this fuel hypothesis should be understood as including the allosteric effect of certain nutrients upon key regulatory enzymes (Malaisse, Sener and MalaisseLagae, 1981c). For instance, the insulinotropic capacity of the nonmetabolized analog of L-leucine, 2-aminobicyclo[2,2,1]-heptane-2-carboxylic acid, is primarily attributable to the activation of glutamate dehydrogenase and, hence, coincides with an increased catabolism of 2-ketoglutarate (Sener and Malaisse, 1980a, b ; Sener, Malaisse-Lagae and Malaisse, 1981 ; Malaisse-Lagae et al., 1982a).

The aim of the present report is to review a recent series of investigations dealing with the metabolism of hexose anomers in pancreatic islets and providing further support for the fuel hypothesis of insulin release.

\section{The metabolism of glucose and mannose anomers in islet cells}

Most aldohexoses examined for such a purpose exist in solution as a mixture of two interconvertible configurations, known as the $\alpha$ - and $\beta$-anomers. The relative abundance of each anomer differs from one sugar to another and this can be accounted for by thermodynamic considerations, the anomeric proportion of monosaccharides being predictible by conformational analysis (Malaisse et al., 1982a).

The $\alpha$-anomers of both D-glucose and D-mannose are better able to stimulate insulin release than the corresponding $\beta$-anomers (Niki et al., 1974 ; Niki, Niki and Miwa, 1979). This finding was first interpreted as supporting the receptor theory for hexose-induced insulin release. However, recent biochemical observations indicate that the anomeric specificity of the insulin secretory response is perfectly compatible with the fuel hypothesis.

In the case of D-glucose, it was already reported 6 years ago that the rates of lactate output and glucose oxidation were higher in islets exposed to the $\alpha$ than to the $\beta$-anomer, the difference apparently being attributable to the $\alpha$ stereospecificity of phosphoglucose isomerase (Malaisse et al., 1976).

Recent studies on the regulation of islet phosphofructokinase activity by hexose-bisphosphates have eventually led to an entirely new view on the metabolism of hexose anomers in islet cells. As reviewed elsewhere (Malaisse, Malaisse-Lagae and Sener, 1982d), the observations that exposure of intact islets to D-glucose results in the activation of phosphofructokinase (Malaisse et al., 1981b), that fructose-2,6-bisphosphate activates phosphofructokinase in islet homogenates (Malaisse et al., 1981b) and that the islets contain the enzyme fructose-6-phosphate,2-kinase (Malaisse, Malaisse-Lagae and Sener, 1981a) suggest a key role for fructose-2,6-bisphosphate in the regulation of glycolysis in islet cells. The validation of this concept requires the measurement of fructose2,6-bisphosphate in islet cells by a specific procedure. In view of the limited amount of tissue readily available, the measurement of fructose-2,6-bisphosphate in the islets has so far been approached only by an indirect method based on the 
activation of purified muscle phosphofructokinase, and the limitation of such a method has been emphasized (Malaisse, Malaisse-Lagae and Sener, 1982c).

In the course of these investigations, it was realized that fructose-2,6bisphosphate was not the sole hexose-bisphosphate able to activate islet phosphofructokinase and that glucose-1,6-bisphosphate also activated this enzyme (Sener, Malaisse-Lagae and Malaisse, 1982b). However, in order to achieve the same extent of activation, the concentration of glucose-1,6bisphosphate had to be approximately 100 times higher than that of fructose-2,6bisphosphate. This difference raised the question as to whether the glucose-1,6bisphosphate content of intact islets exposed to D-glucose is sufficiently high to postulate that this aldohexose-bisphosphate participates, possibly in concert with fructose-2,6-bisphosphate, in the physiological regulation of phosphofructokinase activity. The measurement of the islet glucose-1,6-bisphosphate content has provided an obviously positive answer to this question (Sener, Malaisse-Lagae and Malaisse, 1982b).

These findings and the knowledge that phosphoglucomutase catalyzes the synthesis of glucose-1,6-bisphosphate from glucose-6-phosphate (or glucose-1phosphate) and an appropriate phosphate donor (e.g. fructose-1,6-bisphosphate) led us to measure the activity of phosphoglucomutase in islet homogenates and to consider the possible role of this enzyme in the metabolic response of the islets to hexose epimers and anomers (Malaisse-Lagae, Sener and Malaisse, $1982 \mathrm{c}$ ). It soon became evident that more glucose-1,6-bisphosphate accumulated in islets exposed to $\alpha$ - than to $\beta$-D-glucose. Thus, the higher efficiency of $\alpha$-Dglucose as an insulin secretagogue could not be due solely to the $\alpha$-stereospecificity of phosphoglucose isomerase but also to the well established $\alpha$ stereospecificity of phosphoglucomutase (Salas, Vinuela and Sols, 1965). In other words, both the substrate (fructose-6-phosphate) and the activator (glucose-1,6-bisphosphate) of the reaction catalyzed by phosphofructokinase would be formed at a higher rate in the islets exposed to $\alpha$ - than to $\beta$-D-glucose.

As the last step in this series of investigations, we have scrutinized the possible role of aldohexose-1,6-bisphosphates in the metabolic and secretory responses of the islets to $\alpha$ - and $\beta$-D-mannose, respectively (Malaisse et al., 1982b ; Malaisse-Lagae et al., 1982b ; Sener et al., 1982a). The major results of this study are summarized in table 1. The $\alpha$-anomer of D-mannose increased more than the $\beta$-anomer the rate of insulin release, the $\mathrm{NADH} / \mathrm{NAD}^{+}$and $\mathrm{NADPH} / \mathrm{NADP}{ }^{+}$ratios, the output of lactic acid, the oxidation of mannose and the islet content of aldohexose-bisphosphates. Thus, the greater efficiency of $\alpha$ D-mannose as an insulin secretagogue coincided with a higher rate of glycolysis and the induction of a more reduced state of pyridine nucleotides. These differences in metabolic variables were apparently attributable to a more marked accumulation of aldohexose-bisphosphate, which is likely to result from the $\alpha$ stereospecificity of phosphoglucomutase. The latter enzyme catalyzes the synthesis from mannose-6-phosphate (or mannose-1-phosphate) and fructose-1,6-biphosphate of an activator of phosphoglucomutase, tentatively identified as mannose-1,6-bisphosphate (Malaisse-Lagae, Sener and Malaisse, 1982c). 


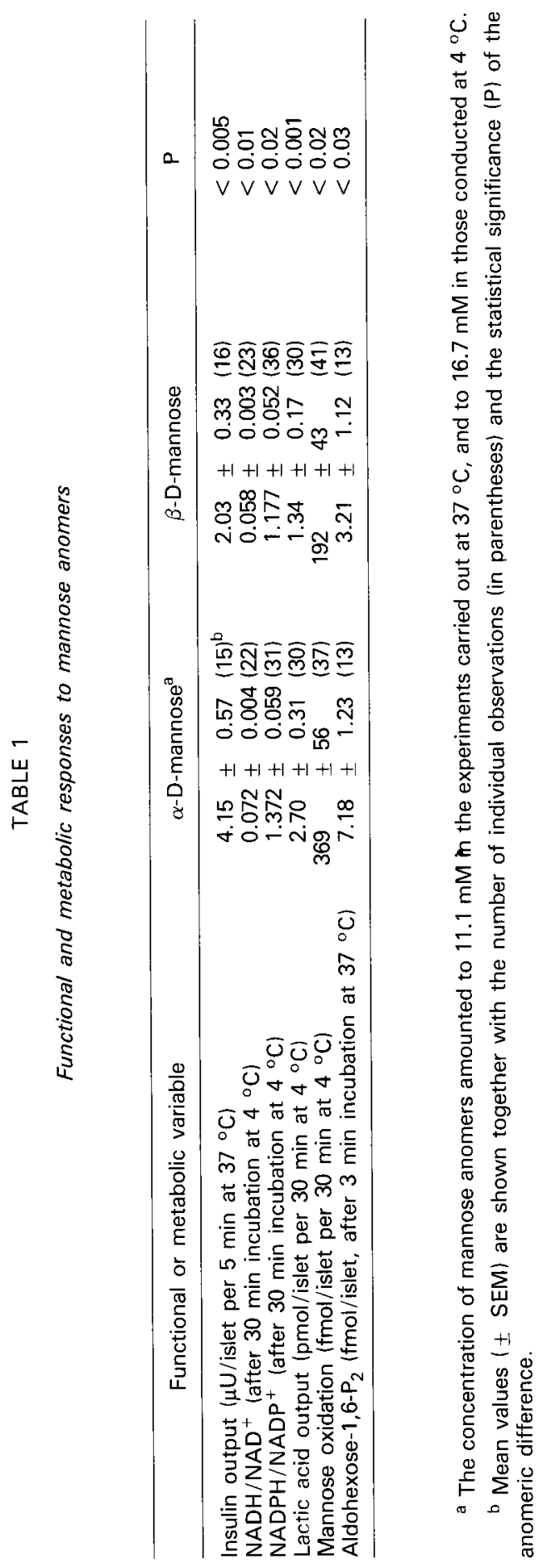




\section{Conclusions.}

In our opinion, these studies on the metabolism of hexose anomers have several implications.

First, they definitely support the fuel hypothesis for insulin release. In this respect, the metabolic results obtained with the anomers of D-mannose are most eloquent since they were usually collected at $4{ }^{\circ} \mathrm{C}$ (in order to delay anomeric equilibration), in which conditions insulin release is abolished. Thus, the difference in catabolic rate cannot be ascribed to a difference in secretory activity.

Secondly, our data convincingly indicate that the glucose-sensor device of islet cells should not be understood as depending solely on glucose phosphorylation but, instead, should be considered within the framework of a series of tightly interrelated reactions, in which the hexose serves as a precursor of both glycolytic intermediates and enzyme activators. In this respect, we cannot agree with the position adopted by those authors who first defended the glucoreceptor theory in its original meaning (i.e. the activation of a receptor by glucose itself independently of any further metabolic event) and now claim that a glucoreceptor indeed exists and is identical with the glucose-phosphorylating enzyme glucokinase (Trus et al., 1981).

Lastly, the study of the metabolism of glucose and mannose anomers in intact cells, which to our knowledge has so far been conducted only in pancreatic islets, illustrates that the anomeric specificity of enzymes may have major functional implications. From a teleological perspective, it is tempting to speculate that living organisms have adapted to the existence of hexose anomers, accounted for by thermodynamic considerations, and, through anomeric specification of enzymes, have developed a subtle system suitable for dissociating the regulation of distinct pathways in the metabolism of the same nutrient (Benkovic and Schray, 1976). The anomeric specificity of enzymes should be taken into account, together with more classical enzymatic regulatory processes such as allosteric activation and induction-repression, in order to reach a full understanding of cellular glucose metabolism.

8e Réunion du groupe Développement I.N.R.A., Tours, 12-13 mai 1982.

Acknowledgements. - The experimental work here under review was supported in part by grants from the Belgian Foundation for Medical Scientific Research. The authors are grateful to C. Demesmaeker for secretarial help.

Résumé. Métabolisme des anomères du glucose et du mannose dans les îlots pancréatiques.

Les $\alpha$-anomères du D-glucose et du D-mannose stimulent la sécrétion d'insuline davantage que les $\beta$-anomères correspondants. Les flux glycolytique et oxydatif sont éga- 
lement plus élevés dans les îlots exposés aux $\alpha$-anomères. Dans le cas de l' $\alpha$-D-glucose, cette situation peut s'expliquer non seulement par I' $\alpha$-stéréospécificité de la phosphoglucose isomérase mais encore par celle de la phosphoglucomutase conduisant à une concentration cellulaire plus élevée de glucose-1,6-bisphosphate, un activateur de la phosphofructokinase. De même, plus d'aldohexose-bisphosphate s'accumule dans les îlots exposés à I' $\alpha$-D-mannose que dans les îlots incubés en présence de $\beta$-D-mannose. La spécificité anomérique du métabolisme des hexoses dans les îlots plaide en faveur de l'hypothèse énergétique pour la sécrétion d'insuline.

\section{References}

BENKOVIC S. J., SCHRAY K. J., 1976. The anomeric specificity of glycolytic enzymes. Adv. Enzymol., 44, 139-164.

MALAISSE W. J., 1972. Hormonal and environmental modification of islet activity, 237-260. In STEINER D. F., FREINKEL N., Endocrine pancreas, Amer. Physiol. Soc., Washington.

MALAISSE W. J., 1973. Insulin secretion : multifactorial regulation for a single process of release. Diabetologia, 9, 167-173.

MALAISSE W. J., 1980. Insulin release : moving towards clarity through sophistication, 143-144. In WALDHÄUSL W. K., Diabetes, 1979, Excerpta Medica, Amsterdam.

MALAISSE W. J., 1981. La sécrétion d'insuline : acquisitions récentes. Rev. Méd. Brux., 2, 379-384.

MALAISSE W. J., DELEERS M., MALAISSE-LAGAE F., SENER A., 1982a. Anomeric specificity of hexose metabolism in pancreatic islets. Excerpta med. int. Congr. Ser., 600 (in press).

MALAISSE W. J., MALAISSE-LAGAE F., LEBRUN P., HERCHUELZ A., LECLERCQ-MEYER V., SENER A., 1982b. Metabolic response of pancreatic islets of the rat to the anomers of Dmannose. Diabetologia, 23, 185.

MALAISSE W. J., MALAISSE-LAGAE F., SENER A., 1981a. Presence of fructose-6-phosphate, 2-kinase in pancreatic islets. FEBS Letters, 135, 203-206.

MALAISSE W. J., MALAISSE-LAGAE F., SENER A., 1982c. Glucose-induced accumulation of fructose-2,6-biphosphate in pancreatic islets. Diabetes, 31, 90-93.

MALAISSE W. J., MALAISSE-LAGAE F., SENER A., 1982d. The glycolytic cascade in pancreatic islets. Diabetologia, 23, 1-5.

MALAisSe W. J., MALAisSe-lagae F., Sener A., VAN SCHAFTINGEN E., HeRS H.-G., $1981 \mathrm{~b}$. Is the glucose-induced stimulation of glycolysis in pancreatic islets attributable to activation of phosphofructokinase by fructose-2,6-bisphosphate ? FEBS Letters, 125, 217 219.

MALAISSE W. J., SENER A., HERCHUELZ A., HUTTON J. C., 1979. Insulin release : the fuel hypothesis. Metabolism, 28, 373-386.

MALAISSE,W. J., SENER A., KOSER M., HERCHUELZ A., 1976. The stimulus-secretion coupling of glucose-induced insulin release. XXIV. The metabolism of $\alpha$ - and $\beta$-D-glucose in isolated islets. J. biol. Chem., 251, 5936-5943.

MALAISSE W. J., SENER A., MALAISSE-LAGAE F., 1981c. Insulin release : reconciliation of the receptor and metabolic hypotheses. Mol. Cell Biochem., 37, 157-165.

MALAISSE W. J., TÄLJEDAL I.-B., 1980. Biochemistry and biophysics of the pancreatic B-cell. Horm. Metab. Res. (suppl. 10), 1-171.

MALAISSE-LAGAE F., SENER A., GARCIA-MORALES P., VALVERDE I., MALAISSE W. J., 1982a. The stimulus-secretion coupling of amino acid-induced insulin release. IX. Influence of a nonmetabolized analog of leucine on the metabolism of glutamine in pancreatic islets. $J$. biol. Chem., 257, 3754-3758.

MALAISSE-LAGAE F., SENER A., LEBRUN P., HERCHUELZ A., LECLERCO-MEYER V., MALAISSE W. J., 1982b. Réponse sécrétoire, ionique et métabolique des îots de Langerhans aux anomères du D-mannose. C. R. Acad. Sci. IIII], Paris, 294, 605-607.

MALAISSE-LAGAE F., SENER A., MALAISSE W. J., 1982c. Phosphoglucomutase : its role in the response of pancreatic islets to glucose epimers and anomers. Biochimie, 64, 1059-1063. 
NIKI A., NIKI H., MIWA I., 1979. Effect of anomers of D-mannose on insulin release from perfused rat pancreas. Endocrinology, 105, 1051-1054.

NIKI A., NIKI H., MIWA I., OKUDA J., 1974. Insulin secretion by anomers of D-glucose. Science, 186, $150-151$.

SALAS M., VINUELA E., SOLS A., 1965. Spontaneous and enzymatically catalyzed anomerization of glucose 6-phosphate and anomeric specificity of related enzymes. J. biol. Chem., 240, 561-568.

SENER A., MALAISSE W. J., 1980a. Activation allostérique de la déshydrogénase glutamique dans les îlots de Langerhans: son rôle dans la libération d'insuline induite par les acides aminés. C. R. Acad. Sci. Paris, Sér. D, 290, 1135-1137.

SENER A., MALAISSE W. J., 1980b. L-leucine and a nonmetabolized analogue activate pancreatic islet glutamate dehydrogenase. Nature, 288, 187-189.

SENER A., MALAISSE-LAGAE F., MALAISSE W. J., 1981. Stimulation of islet metabolism and insulin release by a nonmetabolizable amino acid. Proc. natl. Acad. Sci. (USA), 78, 5460-5464.

SENER A., MALAISSE-LAGAE F., LEBRUN P., HERCHUELZ A., LECLERCQ-MEYER V., MALAISSE W. J., 1982a. Anomeric specificity of D-mannose metabolism in pancreatic islets. Biochem. biophys. Res. Commun., 108, 1567-1573.

SENER A., MALAISSE-LAGAE F., MALAISSE W. J., 1982b. Glucose-induced accumulation of glucose-1,6-bisphosphate in pancreatic islets : its possible role in the regulation of glycolysis. Biochem. biophys. Res. Commun., 104, 1033-1040.

TRUS M. D., ZAWALICH W. S., BURCH P. T., BERNER D. K., WEILL V. A., MATSCHINSKY F. M., 1981. Regulation of glucose metabolism in pancreatic islets. Diabetes, 30, 911-922. 